\title{
Morfometric Variations and Long Weight Relationships Red Eye Snail (Cerithidea obtusa)
}

\author{
Kamaruddin Iwan Eddiwan*, Adriman and Clemen Sihotang
}

Department of Aquatic Resource Management, Aquatic Biology Laboratory, University of Riau, Riau, Indonesia

\begin{abstract}
Red Eye Snail (Cerithidea obtusa) is one species of marine gastropod utilized by coastal communities as a source of animal protein other than fish. Cerithidea obtusa is exploited with varying sizes. This research was conducted at intertidal zone of Pulau Tebing Tinggi beach, Meranti Island regency, Riau from May to June 2017. The objective of the research was to analyse morphometric variation and long-term relationship of Cerithidea obtusa. Samples of Cerithidea obtusa were randomly collected and morphometric parameters measured included shell length, shell width, spire height, shell opening length, shell opening width, and shell depth using digital calipers. The results showed that the long shell of Cerithidea obtusa varied between $21-43 \mathrm{~mm}$, while the width of the shell varied between 13-24 mm. Cerithidea obtusa has a low spire with an oval body shape based on the ratio of shell length to shell width parameters, spire height, shell opening length, shell opening width and shell depth. The relative growth pattern of Cerithidea obtusa is negative allometric.
\end{abstract}

Keywords: Morphometric variation; Length of weight; Cerithidea obtusa

\section{Introduction}

Red Eye Snail (Cerithidea obtusa) is one type of marine gastropod belonging to the family Potamididae. The family of Potamididae is the only Gastropoda family whose members are only found in the mangrove ecosystem. Abbot and Boss state the Potamididae Family in Indonesia, there are approximately ten species in four genera of 29 species worldwide [1]. Ardli ER et al. [2], reported that Cerithidea obtusa is found along the coast in the tropical Indo-Pacific region, especially on the sandy mud substrate associated with the mangrove ecosystem. Cerithidea obtusa is known by the people of the Meranti Islands with the name "siput sedot" and in Indonesia is known by the name "snail red eye". As other types of mollusks found in the coastal areas of the Meranti Islands, Cerithidea obtusa are also found in limited numbers especially in Tebing Tinggi island waters $[3,4]$.

Cerithidea obtusa and other types of gastropods such as kerang darah (Anadara granosa), kerang bulu (Andara antiquata), lola (Trochus niloticus), tujuh tulang mata (Haliotis spp) are often used by communities living in the coastal areas of the Meranti Islands income society. Gastropoda is also used by the people of Riau Islands as one source of animal protein than fish. In the utilization of Cerithidea obtusa, each utilization practitioner can collect about 100-150 Cerithidea obtusa specimens with considerable size variation. On-going utilization activities regardless of the sustainable aspects of this resource have an impact on the decreasing potential of Cerithidea obtusa resources in nature and habitat degradation. Thus, there is a need for management efforts to protect the sustainability of these gastropod species in nature. One of the important information that needs to be learned in the management of marine resources, especially C. obtusa is knowledge of the size distribution and the long-term relation of this species. The research was conducted in the intertidal zone of Meranti Islands with the aim of analyzing morfometric variation of Cerithidea obtusa shell and the long and heavy relationship of Cerithidea obtusa.

\section{Research Methodology}

The study was conducted in the coastal intertidal zone of Meranti Island (Figure 1) in May and June 2017. Sampling of Cerithidea obtusa was conducted at low tide by free collection. The samples were then measured by morphometric shells (Figure 2) which consisted of shell

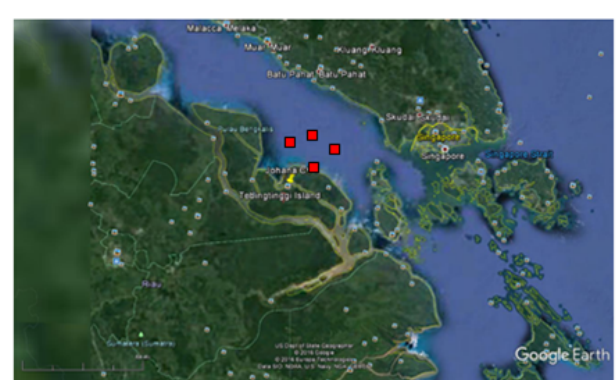

Keterangan:

Study area

Figure 1: Map of study area at Tebing Tinggi coastal waters, Kepulauan Meranti regency.

length (SL), shell width (SW), spire height $(\mathrm{SpH})$, apperture length (AL), shell opening width (AW), shell depth (SD), and weight shell. The samples of Cerithidea obtusa used in this study were 200 samples collected in May and June 2017.

a. Shell Length-SL: Maximum dimensions of apex to umbilicius.

b. Shell Width-SW: The widest part of the shell.

c. High spire (Spire Height-SpH): The distance between apex to last part of "spire whorl".

d. The length of the aperture (Internal Length of Aperture-AL) is measured from the posterior canal to the anterior canal.

e. Width of aperture (Internal width of Aperture-AW): The distance between the base of the columella and the inside of the outer lip.

*Corresponding author: Eddiwan KI, Department of Aquatic Resource Management, Aquatic Biology Laboratory, Faculty of Fisheries and Marine Sciences, University of Riau, Riau 28293, Indonesia, Tel: +965-99179176; E-mail: kamaruddineddiwan@gmail.com

Received October 12, 2017; Accepted October 25, 2017; Published November 03, 2017

Citation: Eddiwan KI, Adriman, Sihotang C (2017) Morfometric Variations and Long Weight Relationships Red Eye Snail (Cerithidea obtusa). J Coast Zone Manag 20: 450. doi: 10.4172/2473-3350.1000450

Copyright: @ 2017 Eddiwan KI, et al. This is an open-access article distributed under the terms of the Creative Commons Attribution License, which permits unrestricted use, distribution, and reproduction in any medium, provided the original author and source are credited. 


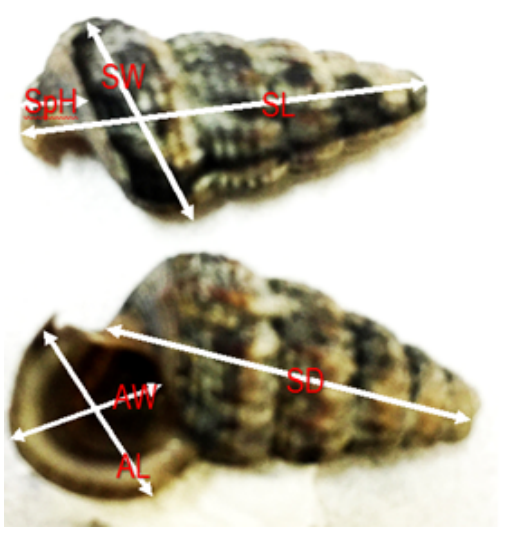

Information:

$\mathrm{SL}=$ Shell length

SW $=$ Shell width

$\mathrm{SpH}=$ Height spiere $(\mathrm{Sph})$

$\mathrm{AL}=$ length of aperture $(\mathrm{AL})$

$\mathrm{AW}=$ Shell opening width (AW)

$\mathrm{SD}=$ Kedalaman cangkang $(\mathrm{SD})$

Figure 2: Sizes of Cerithidea obtusa shells.

f. Shell Depth-SD depth is measured perpendicular to the aperture dimension.

g. The calculated shell dimension ratio is SW/SL, SD/SL, SH/ SL, AL/SL, AW/SL.

The growth pattern of Cerithidea obtusa was analyzed through a long relationship with shell weight with power regression equation according to Effendie:

Formula: $\mathrm{W}=\mathrm{aL}^{\mathrm{b}}$

Where,

W=the weight of the shell Cerithidea obtusa (gram),

$\mathrm{L}=$ the length of the shell $(\mathrm{cm})$,

$\mathrm{a}$ and $\mathrm{b}=$ constants.

\section{Results and Discussion}

\section{Location description}

Meranti Island is located in Tebing Tinggi sub-district, Meranti regency, Riau with an area of $1,438.92 \mathrm{~km}^{2}\left(555.57 \mathrm{mil}^{2}\right)$, bordering with some areas in the north, West Rangsang district in the south, Siak regency in the east, Sub District Tebing Tinggi Timur, and the western borders Tebing Tinggi Barat District. On the shore there is much mangrove vegetation.

Tebing Tinggi Island is an area that is often used by the community as a transportation activity, where fishing, swimming and speed boat, ferry ship between regions, and where people are looking for mangrove wood. These waters are dominated by mud substrate, and are ground and sandy ground level. In addition, these waters have considerable fisheries resources. This can be seen from various types of gastropods especially the family of Potamididae, Strombidae, Neritidae, Trochidae, Angaridae, and various types of mangroves, fires and trees, which can be found around these waters [5-7]. One of the most dominant resources is C. obtusa. C. obtusa is one of the macrobentos animals that have a habit of living in the bottom of the waters and belong to benthic species that are capable of utilizing plankton, and organic materials in the form of detritus present in the mangrove ecosystem [8].

\section{Morphometric variation of cerithidea obtusa shell}

The range of dimensions of Cerithidea obtusa's shell dimensions (Table 1) obtained during the study showed that Cerithidea obtusa found in the intertidal zone of the Tebing Tinggi Islands had a shell

\begin{tabular}{|c|c|c|c|}
\hline Dimensions & $\begin{array}{c}\text { Maximum Size } \\
(\mathbf{m m})\end{array}$ & $\begin{array}{c}\text { Minimum Size } \\
\mathbf{( m m})\end{array}$ & Mean \pm SD \\
\hline Shell length (SL) & 21 & 43 & $22.33 \pm 43$ \\
\hline Shell width (SW) & 13 & 24 & $14.33 \pm 21.33$ \\
\hline Spier height (SpH) & 9 & 13 & $10 \pm 13$ \\
\hline $\begin{array}{c}\text { Shell / aperture aperture } \\
\text { length (AL) }\end{array}$ & 8 & 14 & $9 \pm 13.33$ \\
\hline $\begin{array}{c}\text { Shell opening width } \\
\text { (AW) }\end{array}$ & 9 & 19 & $10.33 \pm 16.67$ \\
\hline Shell depth (SD) & 21 & 35 & $22 \pm 30.33$ \\
\hline
\end{tabular}

Table 1: The range of sizes of Cerithidea obtusa's shell dimensions found in the intertidal zone of Tebing Tinggi island, Meramti Islands, Riau.

length ranging from 21-43 mm with an average shell length of 32.62 $\mathrm{mm}$. Conversely the width of the Cerithidea obtusa shell found in these waters ranges from 13-24 mm. Spire height $(\mathrm{SpH})$ ranges from 9-13 $\mathrm{mm}$, while the shell opening length $(\mathrm{AL})$ ranges from $8-14 \mathrm{~mm}$ with aperture width (AW) range between 9-19 $\mathrm{mm}$. Cerithidea obtusa has a shell depth (SD) ranging from 21-35 mm. According to studies [9], Cerithidea obtusa grows to an average size of $50 \mathrm{~mm}$ but can grow to a size of $80 \mathrm{~mm}$. The rate of growth depends on the local habitat and Cerithidea obtusa can reach its maximum length at the age of two years when it reaches gonad maturity [10].

The results showed that the six dimensions of Cerithidea obtusa's shell were observed and measured in dimensions; the shell length (SL) had the longest average on all four stations. In contrast, the width of the shell openings (AW) has the widest average value at stations 2 and 3 . This is due to the influence of substrate type in this location is the muddy substrate type and there are algae, thus causing the morphological development of the organism to vary [10-12]. Studies [9], stated that different habitats belonging to the same species will have different morphologies, where the habitat of this species is living in mangrove areas, in shallow waters or in watery moisture to a depth of 5 meters.

\section{Shell length-SL}

The dimensions of the shell dimension (SL) of Cerithidea obtusa at each station (Figure 3) show that the dimension of SL ranges from 21-43 $\mathrm{mm}$ with an average value of $32.62 \mathrm{~mm}$. In contrast to station 2, dimension size $21 \mathrm{~mm}$ smallest. This is in contrast to previous research results previously conducted by researchers on some types of gastropods (Table 2).

\section{Maximum size of cerithidea obtusa shell length}

Cerithidea obtusa is still relatively small from the dimensions of its maximum shell length compared to that obtained by other researchers who found the size of the shell length is greater than that found in the intertidal zone on the Coast of Tebing Tinggi Island. This is due to differences in location and time of sampling and conditions of different waters, so the difference in the size of that length occurs. In general, the dimensions of SL or the length of Cerithidea obtusa's shells at all stations appear to be more variable. The smallest shell length at station 2 is lower than that found in stations 1, 3 and 4, but for its maximum shell length relative to the same length. According to studies [11], this is possible because of various supporting factors such as dietary factors, water conditions, predators, competition, and external factors in the form of taking or utilization by the community as a source of food and livelihood.

\section{Shell width-SW shell cerithidea obtusa}

Based on the result of measurement of SW Cerithidea obtusa 

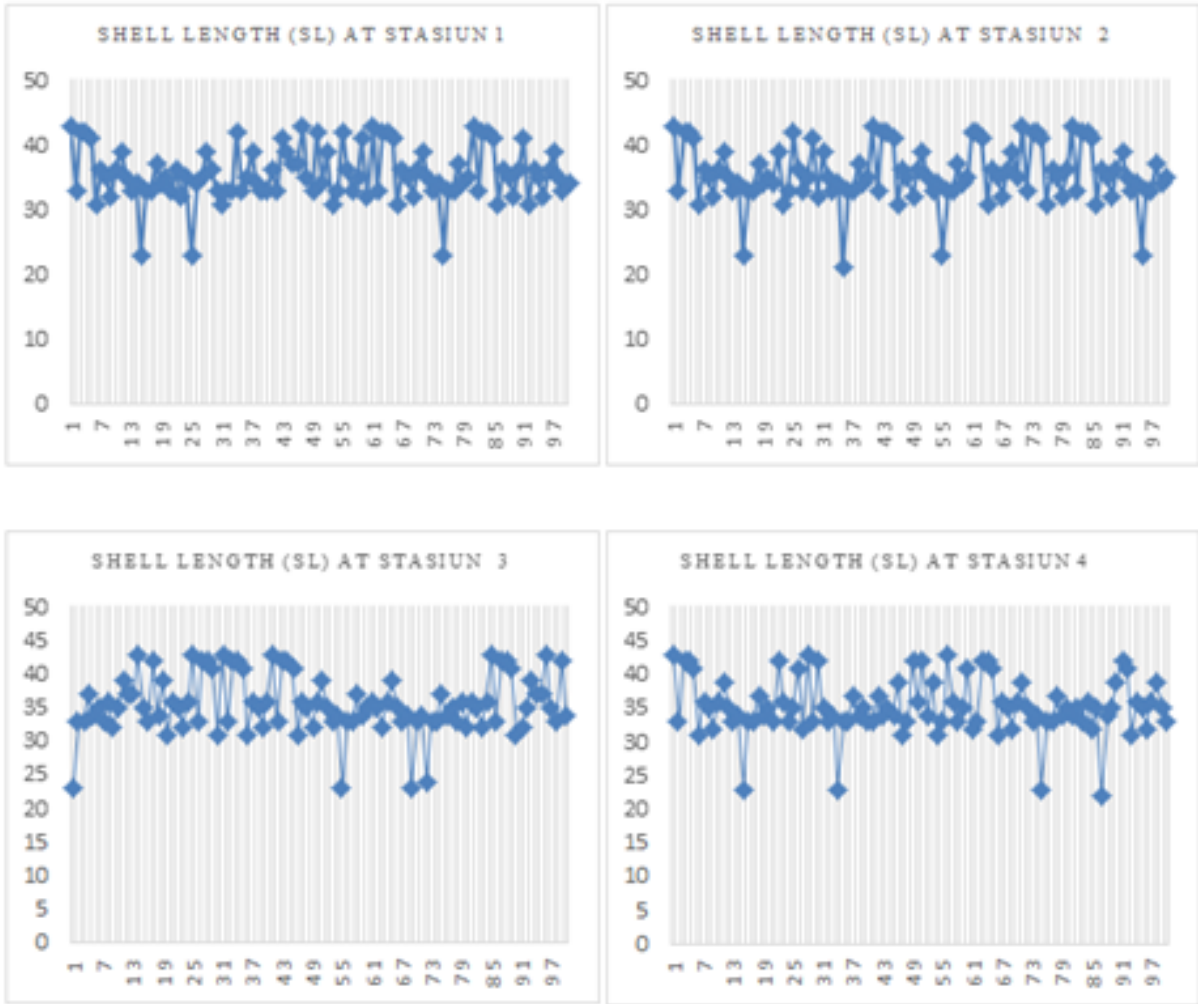

Figure 3: Shell length-SL in station 1, 2, 3, and 4.

\begin{tabular}{|c|c|c|c|c|c|c|c|c|c|c|}
\hline \multirow{3}{*}{ No } & \multirow{3}{*}{ Morphometric } & \multicolumn{8}{|c|}{ Measures Size $(\mathrm{mm})$} & \multirow{3}{*}{ Average $(\mathrm{mm})$} \\
\hline & & \multicolumn{2}{|c|}{ Sta-1 } & \multicolumn{2}{|c|}{ Sta-2 } & \multicolumn{2}{|c|}{ Sta-3 } & \multicolumn{2}{|c|}{ Sta-4 } & \\
\hline & & Smallest & Largest & Smallest & Largest & Smallest & Largest & Smallest & Largest & \\
\hline 1 & Panjang cangkang (SL) & 23 & 42 & 21 & 43 & 23 & 43 & 23 & 43 & 32.625 \\
\hline 2 & Lebar cangkang (SW) & 15 & 19 & 13 & 24 & 14 & 24 & 16 & 16 & 17.63 \\
\hline 3 & Tinggi spiere $(\mathrm{SpH})$ & 10 & 13 & 9 & 13 & 10 & 13 & 11 & 13 & 11.50 \\
\hline 4 & Panjang aperture $(\mathrm{AL})$ & 9 & 14 & 8 & 14 & 9 & 14 & 10 & 12 & 11.25 \\
\hline 5 & Lebar bukaan cangkang (AW) & 11 & 19 & 9 & 18 & 11 & 18 & 11 & 14 & 13.88 \\
\hline 6 & Kedalaman cangkang (SD) & 24 & 35 & 22 & 33 & 23 & 33 & 21 & 25 & 27.00 \\
\hline 7 & Berat cangkang (BC) & 2.80 & 4.80 & 2.35 & 3.40 & 2.75 & 3.40 & 2.95 & 3.00 & 3.18 \\
\hline
\end{tabular}

Table 2: Morphometric red-eye slug (Cerithidea obtusa).

dimension at station 1, 23 and 4 (Figure 4) it is seen that at all stations SW dimension ranged from 13-24 mm with average width of 17.63 $\mathrm{mm}$. At station 2, the smallest size dimension of SW is found to be about $13 \mathrm{~mm}$. In general, the highest average of Cerithidea obtusa shells was found at stations 2 and 3 ranging from $24 \mathrm{~mm}$. This is due to the dimensions of SW or the width of the shell is not always affected by the shell length. If the dimension of the SL is large then the dimensions of the SW may be large, and if the dimension of the SL is small then it can happen also the dimension of its SW will be small, and this is the specification of the type of red-eye slug (Cerithidea obtusa).

\section{High spire (spire height-SpH) cerithidea obtusa shell}

Spire height (SPH) Cerithidea obtusa (Figure 5) found at stations 1, 2,3 , and 4 ranged from $9-13 \mathrm{~mm}$. The average spire height on all stations is $11.50 \mathrm{~mm}$. In contrast to station 2, the smallest spire Cerithidea obtusa spans $9 \mathrm{~mm}$, whereas the highest average $\mathrm{SpH}$ reaches $13 \mathrm{~mm}$ found on all stations. This shows that on all stations, Cerithidea obtusa can grow and develop well. Alternatively, the height of this $\mathrm{SpH}$ is thought to be due to increasing age, the larger the size of the dimensions of the shell, although at the time of reaching the maximum size, Cerithidea obtusa ceases to grow towards this spire height dimension except for the thick dimensions of the lips of this gastropod shell which may increase [12-14].

\section{Shell opening length of aperture length (AL) of cerithidea} obtusa shell

The dimensions of AL fragment of Cerithidea obtusa shell (Figure 6) found at stations $1,2,3$, and 4 ranged from $9-14 \mathrm{~mm}$ with the smallest average value of $9 \mathrm{~mm}$ and the largest average value of $13.5 \mathrm{~mm}$. In general, the highest AL dimensions are at stations 1 and $3(14 \mathrm{~mm})$ and the lowest at station $2(8 \mathrm{~mm})$. This is because AL is influenced by SL and SW. If the SL and SW are large then the dimensions of the AL or the length of the shell opening will be large, otherwise if the SL and SW is small then the value of AL or shell opening will be small.

\section{Shell opening width (AW) cerithidea obtusa shell}

The opening width of the shell (AW) (Figure 7) Cerithidea obtusa at 
stations $1,2,3$, and 4 ranges from 9 to $19 \mathrm{~mm}$ with the smallest average width of $10.5 \mathrm{~mm}$, and the largest average width of $17.25 \mathrm{~mm}$. The AW dimensions of all stations range from 10.5-17.25 $\mathrm{mm}$ with an average of $13.88 \mathrm{~mm}$. Generally the average AW dimension or the highest aperture width is found at station 1, while the lowest AW dimension is found in station 2 . This is thought to be due to the width of this shell opening is inseparable from the shell length (SL) and the shell width (SW). According to recent studies, all the morphological components of Cerithidea obtusa can be interrelated and mutually influential [15-17].

\section{Depth shell (shell depth-SD) shell cerithidea obtusa}

The depth dimension of the shell (SD) Cerithidea obtusa (Figure 8 ) at all stations ranged from $24-35 \mathrm{~mm}$ with the smallest average shell depth of $22.5 \mathrm{~mm}$. And the largest depth average was $31.5 \mathrm{~mm}$. In general, SD dimensions or the highest shell depth are at station 1 (35 $\mathrm{mm}$ ), and lowest $(21 \mathrm{~mm})$ at station 4 . This is because the dimensions of the shell depth are influenced by other dimensions such as shell length (SL), shell width (SW). If these two dimensions have great value then the depth of the shell will also have a great value $[18,19]$.

\section{Cerithidea obtusa shell dimension ratio}

The dimension ratio calculation is performed to compare one dimension with the other dimension for Station 1, 2, 3, and 4. From univariate statistical analysis to dimension ratio of gastropod shell of Cerithidea obtusa it is obtained the mean value, Standard Deviation (Standard Deviation) and variants or variants (Table 3). Table 3 shows that the highest mean SW/SL dimension ratios are found at station 4 (0.696) and the lowest ratios are found at station 4 (0.372). The highest $\mathrm{SD} / \mathrm{SL}$ ratio was found at station $1(0.143)$ and lowest at station 4 $(0,581)$. In contrast the highest average $\mathrm{SpH} / \mathrm{SL}$ dimension ratio was found at station $4(0.0478)$ and the lowest was found at stations 2 and 4 (0.302). The average shell length or aperture length $(\mathrm{AL})$ ratio of shell length (SL) (AL/SL) (Figure 4) was found to be the largest in station 4 (0.435) and the lowest ratio was found at station $1(0.279)$. In contrast the highest average AW/SL ratio was found at stations 1,3 and 4 (0.478), and the lowest at station $4(0.326)$.

From Chi-Square test result to mean value, standard error and variance of calculation for each station from the ratio of Cerithidea

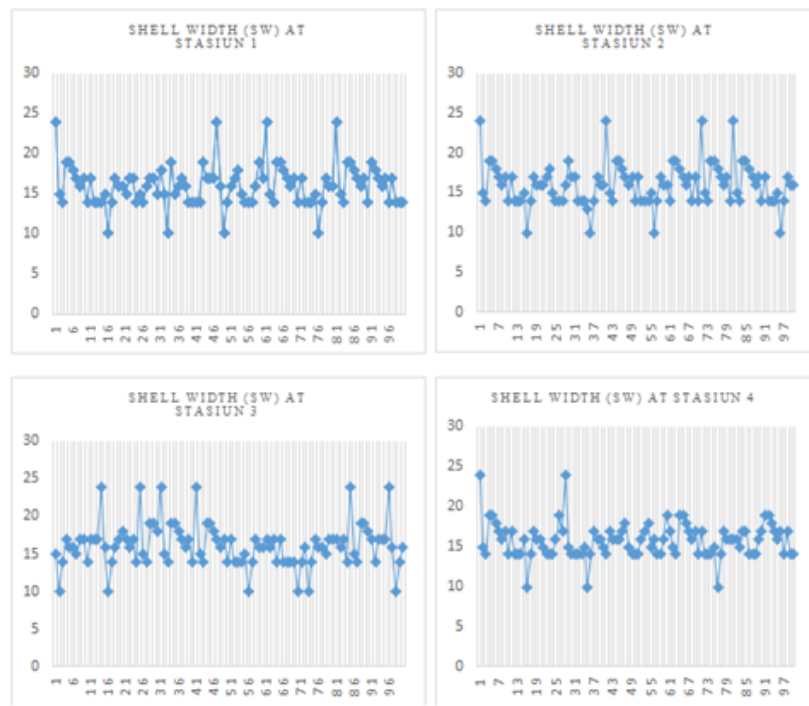

Figure 4: Shell width-SW on station 1, 2, 3, and 4.

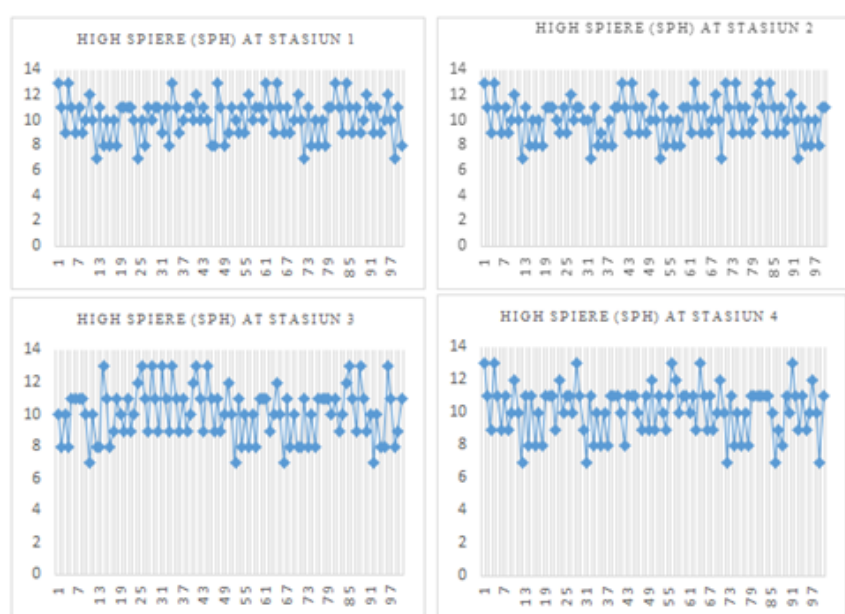

Figure 5: Spire height ( $\mathrm{SpH})$ of Cerithidea obtusa shells on station 1, 2, 3, and 4 .

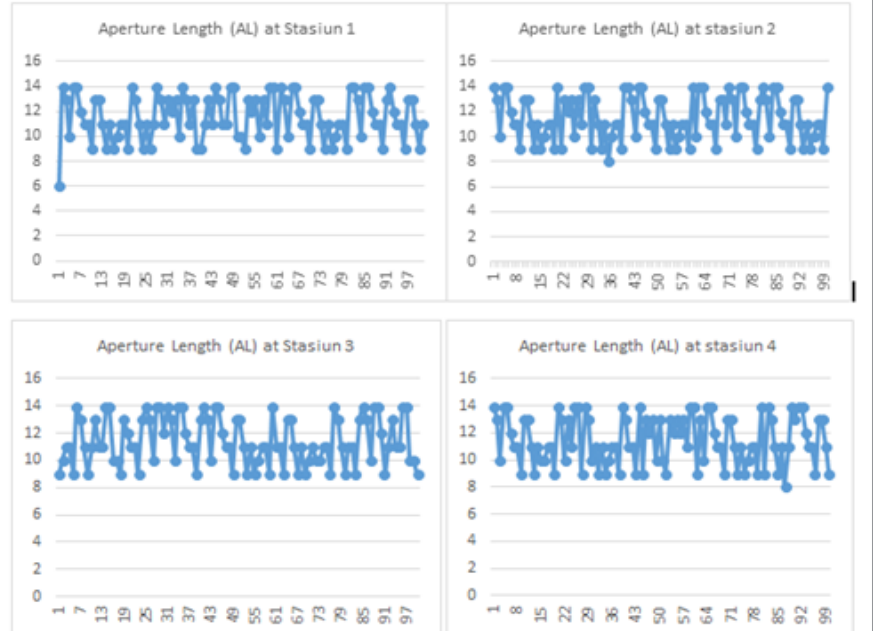

Figure 6: Dimensions the length of the shell opening (Aperture Length-AL) of Cerithidea obtusa shells on stations 1,2, 3, and 4.

obtusa on dimension of all stations. Where at station $1(\mathrm{Ho})$ is not equal to 1 , and $(\mathrm{Ha})$ is different from 1 . Therefore the calculated $\mathrm{p}$ value is lower than the level of significance of alpha $(\alpha=0.05)$, so the null hypothesis (Ho) must be rejected, and accept alternative hypothesis (Ha) which means rejecting the null hypothesis (Ho) which is lower than $1.85 \%$. Furthermore, at station 2 (Ho) the difference is equal to 1 , and $(\mathrm{Ha})$ the difference is different from 1 . Therefore, the calculated $p$ value is lower than the alpha significance level $(\alpha=0.05)$, then the null hypothesis (Ho) must be rejected and accept alternative hypothesis (Ha). Which means rejecting the correct Ho-zero hypotheses is lower than $2.11 \%$. Furthermore, for station 3 (Ho) the difference is equal to 1 , and $(\mathrm{Ha})$ the difference is different from 1 . Since the calculated $\mathrm{p}$ value is lower than the alpha significance level $(\alpha=0.05)$, then the null hypothesis (Ho) must be rejected, and accept the alternative hypothesis (Ha) which means rejecting the null hypothesis (Ho) which is lower than $1.38 \%$. Then for station 4 (Ho) the difference is equal to 1 and (Ha) the difference is different from 1 . Since the calculated $\mathrm{p}$ value is lower than the alpha significance level $(\alpha=0.05)$, the null hypothesis must reject, alternative hypothesis $(\mathrm{Ha})$ which means rejecting the null 


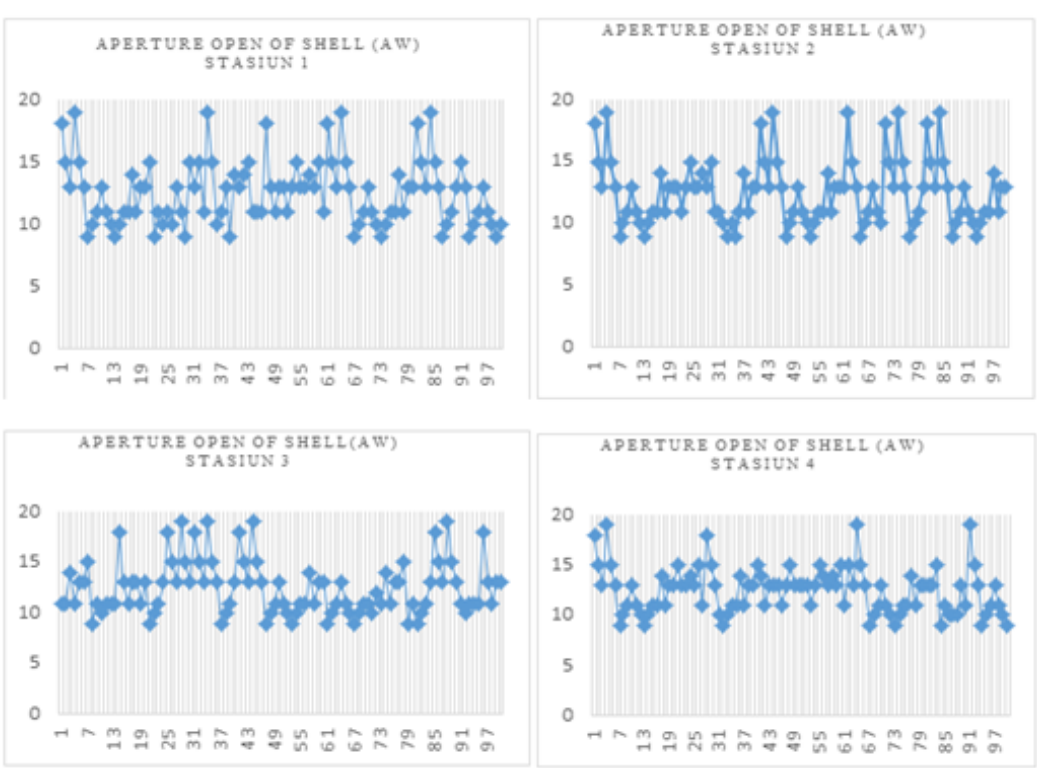

Figure 7: Dimension of shell open aperture (AW) Cerithidea obtusa at station 1, 2, 3, and 4.
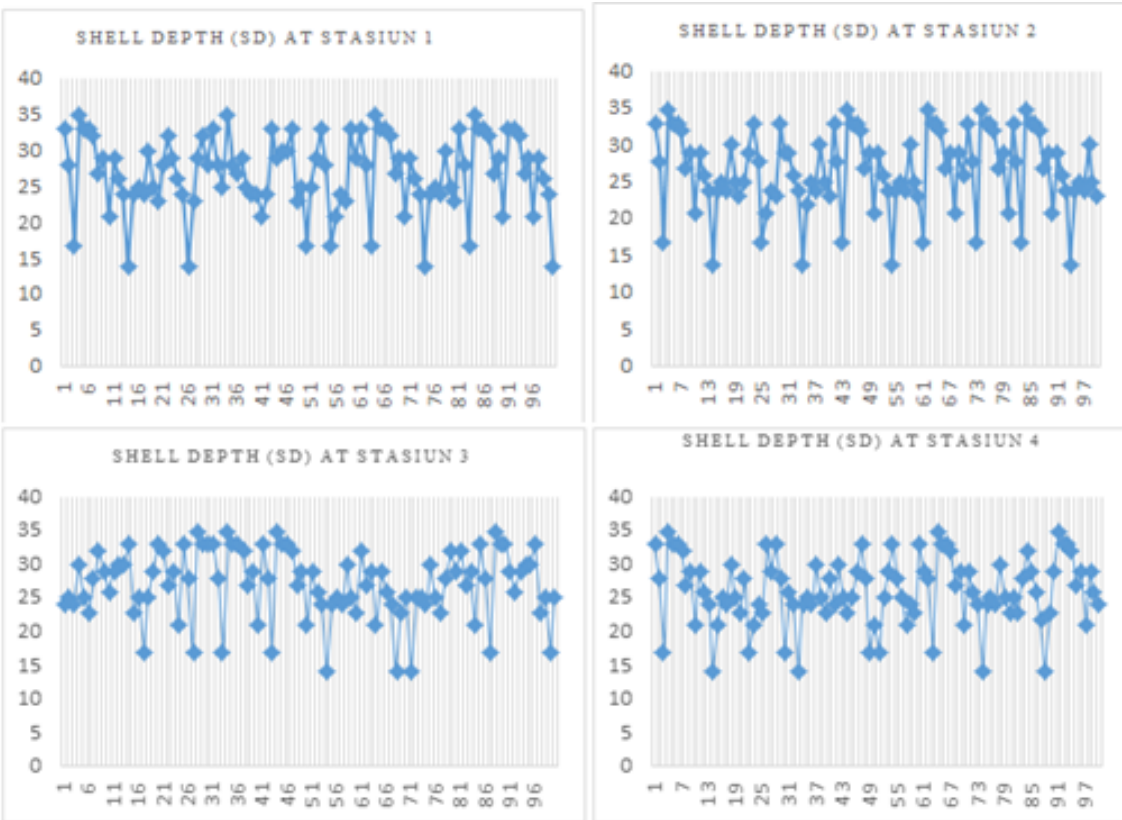

Figure 8: Dimension of shell open aperture (AW) Cerithidea obtusa at station 1, 2, 3, and 4.

\begin{tabular}{|c|c|c|c|c|c|c|c|c|c|}
\hline \multirow{3}{*}{$\begin{array}{c}\text { Shell Dimension of } \\
\text { Ratio }\end{array}$} & \multicolumn{8}{|c|}{ MEASURES SIZE ( mm ) } & \multirow{3}{*}{$\begin{array}{l}\text { Average } \\
(\mathrm{mm})\end{array}$} \\
\hline & \multicolumn{2}{|c|}{ Sta-1 } & \multicolumn{2}{|c|}{ Sta-2 } & \multicolumn{2}{|c|}{ Sta-3 } & \multicolumn{2}{|c|}{ Sta-4 } & \\
\hline & Smallest & Largest & Smallest & Largest & Smallest & Largest & Smallest & Largest & \\
\hline SW/SL & 0.652 & 0.452 & 0.619 & 0.558 & 0.609 & 0.558 & 0.696 & 0.372 & 0.565 \\
\hline $\mathrm{SD} / \mathrm{SL}$ & 1.043 & 0.833 & 1.048 & 0.767 & 1.000 & 0.767 & 0.913 & 0.581 & 0.869 \\
\hline $\mathrm{SpH} / \mathrm{SL}$ & 0.435 & 0.310 & 0.429 & 0.302 & 0.435 & 0.302 & 0.478 & 0.302 & 0.374 \\
\hline AL/SL & 0.391 & 0.333 & 0.381 & 0.326 & 0.391 & 0.326 & 0.435 & 0.279 & 0.358 \\
\hline AW/SL & 0.478 & 0.452 & 0.429 & 0.419 & 0.478 & 0.419 & 0.478 & 0.326 & 0.435 \\
\hline
\end{tabular}

Table 3: The dimension ratio of Cerithidea obtusa.

hypothesis of Ho lower than $0.64 \%$.

From the result of Chi-Square test to SW/Sl it is known that Ho has the same variance as 1 and $\mathrm{Ha}$ variance is different from 1 . Since the calculated $\mathrm{p}$ value is lower than the level of significance alpha $(=0,05)$, 
the null hypothesis) must be rejected, and accept alternative hypothesis (Ha). Which means rejecting the null hypothesis $(\mathrm{Ho})$ lower than $0.02 \%$. For the SD/SL dimension it is known that the $\mathrm{H} 0$ variance is equal to 1 , and the Ha variance is different from 1 . Since the calculated $\mathrm{p}$ value is lower than the alpha significance level $(\alpha=0.05)$, the null hypothesis (Ho) must be rejected, alternative hypothesis $(\mathrm{Ha})$. Which means rejecting the null hypothesis $(\mathrm{Ho})$ lower than $0.07 \%$. The variance $(\mathrm{H})$ is equal to 1 , and $(\mathrm{Ha})$ the variance is different from 1 . Since the calculated $\mathrm{p}$ value is lower than the alpha significance level $(\alpha=0.05)$, the null hypothesis (Ho) must be rejected, and accept alternative hypothesis (Ha). Which means rejecting the null hypothesis $(\mathrm{Ho})$ is lower than $0.01 \%$. Then for the dimension of SpH/SL hypothesis (Ho) the variance is equal to 1 and $(\mathrm{Ha})$ the variance is different from 1 . Since the calculated $\mathrm{p}$ value is lower than the alpha significance level $(\alpha=0.05)$, the null hypothesis (Ho) and accept the alternative hypothesis (Ha). This means rejecting the null hypothesis (Ho) lower than $0.01 \%$. Furthermore, for AW/SL dimension, where Ho has a difference between the mean equal to 0 , and Ha has the difference between mean different with 0 . Since the $\mathrm{p}$ value calculated is lower than the level of significance alpha $(\alpha=0.05)$, the null hypothesis Ho) must refuse, and accept alternative hypothesis (Ha) which means rejecting the null hypothesis (Ho) is lower than $0.01 \%$.

\section{SW/SL dimension ratio}

From the results of data analysis during the study at stations 1, 2, 3 , and 4 found the highest average ratio of SW/SL (Figure 4) to station 4 (0.696) with standard deviation (0.039) and the lowest average was found on station 4 by 0.609 . During this study, the SW size is smaller than the SL dimension so that the shape of Cerithidea obtusa's shell is oval or round.

\section{$\mathrm{SD} / \mathrm{SL}$ dimension ratio}

Based on data analysis for SD/SL dimension ratio (Figure 4), the highest average SD/SL dimension ratio was found at station $2(1,048)$ with standard deviation of 0.062 and lowest at station 4 (0.913). During this study, the dimension of SL is larger than the SD dimension, so the shape of Cerithidea obtusa's shell is oval or elongated.

\section{$\mathrm{SpH} / \mathrm{SL}$ dimension rate}

The result of data analysis to SpH/SL dimension ratio (Figure 4) shows that the mean of the highest SH / SL dimension ratio at station month 4 is 0.478 with standard deviation 0.023 and lowest at station (0.429). During this study, the size of the $\mathrm{SpH}$ is smaller than the SL dimension so that the shape of the Ceritidea obtusa gastropod shell is oval or rounded or circular.

\section{$\mathrm{AW} / \mathrm{SL}$ dimension ratio}

The result of data analysis to AW/SL dimension ratio (Figure 4) shows that the highest AW/SL dimension ratio is found at station 3 that is $0.478 \mathrm{~mm}$ with the standard deviation value 0.025 and the lowest average ratio at station $4(0.466)$. During this study, the size of AL is smaller than the size of SL so that the shape of the shell Cerithidea obtusa is oval or round.

\section{Long relationship and shell weight cerithidea obtusa}

Based on result of analysis of long and heavy relation of Cerithidea obtusa shell at all station (1,2,3 and 4) (Figure 5) we can get the estimation model of heavy relation weights $\mathrm{W}=30,766 \mathrm{~L} 1,6028$ with determinant coefficient value $(R 2)=0.0866$, and the regression value $(r)=0.2942$. By using $t$ test to $b$ value, obtained coefficient $b \neq 3$ with $t$ value $=37.8140>t$ table $=1.8909$ at $95 \%$ confidence level. The result of analysis shows that the value of $b$ obtained is $b=1.6028$. This means that the value of $b$ obtained $<3$. This shows that the relative growth pattern of Cerithidea obtusa is negative allometric $(\mathrm{b}<3)$ which means that the rate of increase in length and total weight of Cerithidea obtusa shell is unbalanced, meaning that the weight gain is slower than the increase long [20].

Result of analysis of shell weight relation to shell length of Cerithidea obtusa at station 1,2,3 and 4 obtained the estimation model of long relationship of weight is $\mathrm{W}=0,0347 \mathrm{~L} 0,0899$ with determinant coefficient value (R2) equal to 0,2359 , and value regression of $r=0.2942$ (Figure 5). By using $t$ test to the value of $b$ obtained coefficient $b \neq 3$ with value $t$ hit $=37.8140>t$ table $=1.8909$ at $95 \%$ confidence level. This suggests that the relative growth pattern of Cerithidea obtusa is negative allometric $(b<3)$, which means that the rate of increase in length and total weight of Cerithidea obtusa shell is unbalanced, meaning that the length increase is faster than weight gain.

In general it can be said that the results of the analysis of long and heavy relationship of shell Cerithidea obtusa showed that the growth pattern of Cerithidea obtusa in intertidal waters of Tebing Tinggi Island of Meranti Island is negative allometric, which means that its length increase is faster than its weight gain. The results of research conducted on snail barks (Strombus canarium) also found a relative growth pattern of snails barks are also negative allometricm [21].

\section{Conclusion}

1. Mean dimensions of Cerithidea obtusa shells measured by morphometric variation, all dimensions of the shell except the highest depth of shell depth were found in stations $1,2,3$, and 4 .

2. The highest mean dimension ratios are found in Station 2 on the SD / SL dimension ratio.

3. Shape of Cerithidea obtusa shell is oval or rounded based on the dimensions of the shell dimensions analyzed.

4. The relative growth pattern of Cerithidea obtusa's red-eye slug is negative allometric.

\section{References}

1. Abbot RT, KJ Boss (1989) A classification of the living molusca. American Malcologist, Inc., Florida, USA.

2. Ardli ER, Edi Y, Widyastuti A (2010) Spatial distribution and population dynamics of polymesoda erosa in mangrove ecosystem segara anakan cilacap as reference restocking and conservation. Report of Research Results, University of General Soedirman (Indonesia).

3. Ayunda R (2011) Community structure of gastropoda on mangrove ecosystem in Pulau Pari Kepulauan Seribu Island. University of Indonesia, Jakarta (Indonesia).

4. Berg CJ (1974) A comparative ecological studiesw of strombid gastrowpods Behavior 51: 274-321.

5. Catterall C, Poiner IR (1983) Age and dependent pattern of aggregation in the tropical gastropod Strombus luhuanus. Marine Biology 77: 171-182.

6. Dance SP (1976) The encyclopedia of shells. Blandford Press, London.

7. Dharma B (1988) Snail and shellfish Indonesia (Indonesia Shells I) ConchBooks, Germany.

8. Dharma B (2005) Recent and fossil of Indonesia shells. ConchBook, Germany

9. Effendie MI (1979) Method of fisheries biology. Yayasan Dewi Sri, Bogor.

10. Haumahu S (2011) Distribution of Strombidae in the intertidal zone around the waters of the Lease Islands, Central Maluku. J Water Resource Management 7: $42-51$.

11. Haumahu S (2011) Community diversity molluscs in intertidal zone around 
Citation: Eddiwan KI, Adriman, Sihotang C (2017) Morfometric Variations and Long Weight Relationships Red Eye Snail (Cerithidea obtusa). J Coast Zone Manag 20: 450. doi: 10.4172/2473-3350.1000450

Page 7 of 7

Saparua Strait Waters, Central Maluku. (Indonesia).

12. Oliver APH (1975) The Hamlyn guide to the shells of the world. Hamlyn Publising Group, Hong Kong.

13. Poutiers JM (1998) Gastropods. The living marine resources of the Western Central Pacific. In: Carpenter KE, Niem VH. FAO Species Identification Guide for Fishery Purposes. pp: 363-646.

14. Reid DG (2014) The genus Cerithidea Swainson, 1840 (Gastropoda: Potamididae) in the Indo-West Pacific region. Zootaxa 3775: 1-65.

15. Rusnaningsih (2012) Community structure of gastropod and population study of Cerithidea obtusa Lammark in Pangkal Babu Mangrove forest, Tanjung Jabung Barat district, Jambi. Jakarta, Indonesia.

16. Tan SK, Clements R (2008) Taxonomy and distribution of the Neritidae
(Mollusca: Gastropoda) in Singapore. Zoological Studies 47: 481-494.

17. Tis'in M (2008) Mangrove typology and its linkage to Gastropoda population Littorina neritoides in Tankeke Islands, Takalar District, South Sulawesi. Bogor Agricultural University, Indonesia.

18. Uneputty PA (2005) Mollusc diversity in coastal waters of South Buru.

19. Uneputty PA (2006) Inventory of molluscs for traditional medicine on the Lease islands.

20. Utami DK (2012) Bio-ecological studies of snail barks (Strombus turturella) in Bakit Village, Klabat Bay West Bangka Regency, Bangka Belitung Islands Province.

21. Wilson BR (1993) Australia marine shells. Prosobranch Gastropods. Part one. Kallroo, Odyssey. pp: 407. 